\title{
Forgiveness among Javanese College Students: The Role of Cultural Values and Personality Trait
}

\author{
Fuad Nashori ${ }^{1}$, Raden Rachmy Diana ${ }^{2}$, Muthia Rahma Syamila ${ }^{3}$, Bahril Hidayat ${ }^{4}$, Yudi \\ Kurniawan ${ }^{5}$, Nyda Afsari ${ }^{6}$ \\ \{fuadnashori@uii.ac.id ${ }^{1}$, raden.diana@uin-suka.ac.id 2 ,19321117@students.uii.ac.id $\}$
}

\author{
Department of Psychology, Faculty of Psychology and Socio-Cultural Sciences, Universitas \\ Islam Indonesia, Yogyakarta, Indonesia ${ }^{l}$, Department of Psychology, Faculty of Social \\ Sciences and Humanities, Universitas Islam Negeri Sunan Kalijaga, Yogyakarta, Indonesia ${ }^{2}$, \\ Department of Communication, Faculty of Psychology and Socio-Cultural Sciences, \\ Universitas Islam Indonesia, Yogyakarta, Indonesia ${ }^{3}$
}

\begin{abstract}
This present study is aimed to find out the correlation between Javanese cultural values orientation, personality trait, and forgiveness among Javanese college students. We propose several hypothesis: (a) there would be a positive and significant correlation between Javanese cultural values orientation and forgiveness, (b) there would be a positive and significant correlation between agreeableness, openness, conscientiousness, extraversion and forgiveness, (c) there would be a negative and significant correlation between neuroticism and forgiveness. A hundred students participated this study by filling out three questionnaires: forgiveness scale, cultural value orientation scale, and personality trait scale. Pearson correlation analysis shows that all hypothesis was accepted.
\end{abstract}

Keywords: Forgiveness, cultural values, agreeableness, neuroticism, conscientiousness, openness, extraversion, Javanese.

\section{Introduction}

Forgiveness is an attempt to react on violation in which a person turns negative response to neutral or positive one [1]. Forgiveness significantly contributes in human's life quality. Forgiveness makes individual feels happy and free from negative emotions [2,3] optimizes mental health [4,5], improves spirituality in dealing with post- traumatic [6], increases resilience [7], improves the positive aspect of stress [8], and decreases bullying [9]

Forgiveness needs to be further studied for there are chances where individual can experience trauma and it may cause despair. A survey by Nashori, Iskandar, Setiono, and Siswadi [10] finds that Indonesian students who live and study in Yogyakarta, a center of Javanese culture, experience many kinds of mistreatment. Among 42 subjects, there are 39 subjects $(92.8 \%)$ who offer forgiveness and 3 subjects $(7.2 \%)$ who find it hard to forgive their offenders. In addition, among 39 subjects who offer forgiveness, 29 subjects (74\%) offer forgiveness committedly and 10 subjects $(26 \%)$ offer forgiveness with conditionally. 
Javanese college students encounter various life issues like students at large. A study by Nashori, Iskandar, Setiono, and Siswadi [11] mentions that Javanese who lives in Yogyakarta have low level of forgiveness (16.7\%) and medium level of forgiveness (67.8\%). As a part of Javanese society, the students live the principles of Javanese culture. Kuntari [12] states that Javanese culture teaches individual to recall the kindness of others and overlook their mistakes (in Javanese: mikul dhuwur mendhem jero) and able to give in for a better life at a later time (wani ngalah luhur wekasane). These principles inspire the Javanese college students in responding to life issues rationally.

Forgiveness that individual demonstrates are influenced by several factors. One of them is cultural value. It is shown in Benedict's research [13] that culture can create pleasant and affectionate individuals. When the culture nurtures positive values, it creates positive attitudes among individuals who live in it. Accordingly, it includes forgiveness. Benedict's conclusion is based on an in-depth study in numerous Indian tribes in America, like Zuni, Arapesh, Dakota, and Eskimo.

When it is adapted to the context of Javanese culture, it can be said that life values in the culture will encourage forgiveness among Javanese. The orientation of Javanese cultural values has three dimensions, namely self-orientation, religious orientation, and collective orientation [14]. Nurwianti and Oriza [15] mention that an ethnic can significantly demonstrate forgiveness since its values put emphasis on its relation with God. In this ethnic, a forgiving God inspires the devotees to be forgiving too.

In addition, forgiveness is closely related to personality traits. McCullough [16] is the expert that highlights the relation between personality traits and forgiveness. The conclusion is strengthened with an empirical finding by Firdaus [17] which mentions that openness, agreeableness, and extraversion are positively correlated to forgiveness. Meanwhile, neuroticism and conscientiousness are negatively correlated to forgiveness. Thus, traits, like, openness, agreeableness, and extraversion, can be the predictors of forgiveness.

Also, level of education contributes in forgiveness. Nashori, Iskandar, Setiono, and Siswadi [11] mentions that people who are highly educated have higher level of forgiveness. These people have more chances to learn together than those with lower level of education. Learning together enables them to treat one another properly. Forgiveness becomes a social capital that enable people to live side by side peacefully.

Based on the aforementioned explanation, this research aims to find the influence of Javanese cultural values, personality traits, and level of education to forgiveness. The hypotheses of the research are: (a) there is a positive correlation between Javanese cultural values and forgiveness among the students, (b) there is a positive correlation among openness, agreeableness, and extraversion with forgiveness, (c) there is a negative correlation among neuroticism and conscientiousness with forgiveness, and (d) there is a difference on forgiveness between undergraduate students and graduate students, as those with higher education has higher level of forgiveness

\section{Method}

\subsection{Participants}

The participants of this research were Javanese college students who studied in the undergraduate and graduate program of Psychology, Faculty of Psychology and SocioCultural Sciences, Universitas Islam Indonesia (UII) and Faculty of Social Sciences and Humanities Universitas Islam Negeri (UIN Sunan Kalijaga) Yogyakarta, Indonesia. The 
number of participants were 100 students that consisted of 30 undergraduate students and 70 graduate students. The subject was 71 UII students and 29 UIN Sunan Kalijaga students. There were 40 male students and 60 female students and in the age of 19-35.

\subsection{Data Collection Method}

The measuring instruments used in this research were forgiveness, orientation of Javanese cultural value, and personality scale. Forgiveness scale was adapted by Subandi [18] from Thompson et al [1] with total-item correlation coefficient between $0.306-0.482$ and reliability with Alpha Cronbach coefficient 0.803. The second measuring instrument is Javanese cultural values orientation scale by Idrus [14] has total-item correlation coefficient between $0.3019-0.6684$ and reliability with Alpha Cronbach coefficient 0.957 . Personality trait scale was adapted by Firdaus [17] from Costa and McCrae [19]. This scale has total-item correlation coefficient between 0.259-0.601 with Alpha Cronbach coefficient 0.853.

\subsection{Data Analysis Technique}

The research used product moment analysis to illustrate the correlation between Javanese cultural values and forgiveness variables, as well as between personality traits and forgiveness variables. Additionally, the research also used t-test analysis with discrimination testing. The testing aimed to find the difference in forgiveness among undergraduate and graduate students.

\section{Result}

\subsection{Cultural Value and Forgiveness}

After checking normality and linearity of the data, the researchers conduct hypothesis testing. The results of product moment correlation analysis show that there is a significant positive correlation between Javanese cultural value and forgiveness $(r=0.227 ; \mathrm{p}<0.05)$. Furthermore, the results also show: (a) there is a very significant positive correlation between self- orientation value and forgiveness $(\mathrm{r}=0.321 ; \mathrm{p}<0.01)$, (b) there is a very significant positive correlation between religious orientation value and forgiveness $(r=0.284, p<0.01)$, (c) there is no correlation between collective orientation value and forgiveness $(r=0.025 ; \mathrm{p}>0.05)$. Besides, there is a relative contribution of Javanese cultural value orientation to forgiveness as $5.15 \%$.

\subsection{Personality Traits and Forgiveness} Table 1

The results of product moment correlation analysis and hypothesis testing presented in

Table 1. Hypothesis Testing on the Correlation Between Personality and Forgiveness

\begin{tabular}{|c|c|c|c|}
\hline Aspects & $\mathbf{R}$ & p-value & R Square* \\
\hline $\begin{array}{l}\text { Forgiveness } \\
\text { Neuroticism }\end{array}$ & -0.459 & 0.000 & $\begin{array}{l}0.210681 \\
(21.07 \%)\end{array}$ \\
\hline $\begin{array}{l}\text { Forgiveness } \\
\text { Extraversion }\end{array}$ & 0.298 & 0.003 & $\begin{array}{c}0.088804 \\
(8.88 \%)\end{array}$ \\
\hline $\begin{array}{l}\text { Forgiveness } \\
\text { Conscientiousnes }\end{array}$ & 0.367 & 0.000 & $\begin{array}{l}0.134689 \\
(13.47 \%)\end{array}$ \\
\hline $\begin{array}{l}\text { Forgiveness } \\
\text { Openness }\end{array}$ & 0.461 & 0.000 & $\begin{array}{l}0.212521 \\
(21.25 \%)\end{array}$ \\
\hline $\begin{array}{l}\text { Forgiveness } \\
\text { Agreeableness }\end{array}$ & 0.341 & 0.001 & $\begin{array}{l}0.116281 \\
(11.63 \%)\end{array}$ \\
\hline
\end{tabular}


Table 1 shows: (a) there is a significant negative correlation between neuroticism and forgiveness $(\mathrm{r}=-\mathrm{0}-459, \mathrm{p}<0.000)$, (b) there is a significant positive correlation between extraversion and forgiveness $(\mathrm{r}=0.298 \mathrm{p}=0.003)$, (c) there is a significant positive correlation between conscientiousness and forgiveness $(\mathrm{r}=367, \mathrm{p}=0.000)$, (d) there is a significant positive correlation between openness and forgiveness $(\mathrm{r}=0.461, \mathrm{p}=0.000)$, and (e) there is a significant positive correlation between agreeableness and forgiveness $(\mathrm{r}=0.341, \mathrm{p}=0.000)$.

\section{Discussion}

\subsection{Javanese Cultural Values and Forgiveness}

The results show that there is a positive correlation between Javanese cultural values and forgiveness among Javanese college students. It is compatible with Benedict's viewpoint [13] which illustrates the influence of cultural value to a person's attitudes, including forgiveness.

Koentjaraningrat [20] asserts that cultural value is the highest and the most abstract form of culture since it covers concepts in subconscious mind believed by the society. It is considered well- intentioned, valuable, and essential in life; therefore, the value can function as a way of life. According to Suharsono and Susetyo [21] there are fifteen characteristics of forgiveness among Javanese college students according to collectivistic cultural context. However, there are three distinctive characteristics, namely, condone (22\%), networking $(27 \%)$ and positive attitudes $(10.2 \%)$. In dealing with complicated dispute, Javanese college students are able to letting go and forget the dispute as it gives them peaceful mind [21]

Idrus [14] mentions that Javanese cultural values covers aspects, like, self-orientation, collective orientation, and religious orientation, that demonstrate significant correlation with forgiveness. In general, the results clarify that forgiveness that a person offered is influenced by positive values in his/her internal condition and closely related to his/her religious relation. Knowledge on religious values can strengthen a person's understanding on forgiveness concept [22]. In addition, forgiveness process can also be interpreted as intrapersonal experience attached to social relation context and involved a particular mistake [23]. It later characterizes self-worth that influences forgiveness. On the other hand, collective relationship orientation does not have any significant correlation with forgiveness.

Religious orientation consists of narima (compliance), dedication, and eling (remembering the God) [14]. Religious orientation and forgiveness, according to MagnisSuseno [24], is an act of narima that will help a person in handling abuse. Narima means accepting a condition without complaining. Furthermore, Nashori and Setiono [25] explain that eling is an important value that influences forgiveness. One of its principles which is closely related to religious orientation is ojo lali saben ari eling mareng Pangeranira (remember God every day). By remembering God, Javanese will easily get insight to forgive since God is forgiving and loves person who forgives other. A study by Nashori, Iskandar, Setiono, and Siswadi [10] indicates that self-forgiveness relies on a faith that God is the source of power for forgiveness, to be as forgiving as God does, to believe in hard times as God's test, to believe in God's scenario, and to stay positive in God's will.

The specified results illustrate the significant role of religious orientation to forgiveness; thus, it strengthens prior studies. Culture which lays strong emphasis on religion will put forward its relation to God and creates individuals who upholds forgiveness. Nurwianti and Oriza [15] conducted a research to 1,066 respondents (540 males and 526 females) who were between 18-55 years and belonged to some major ethnics in Indonesia, such as, Javanese, Sundanese, Betawinese, Minangese, Batakese, and Bugisese. The result indicates that 
Minangese has the highest forgiveness score among other ethnics as these people believe in adat basandi syara', syara' basandi kitabullah (custom is based on sharia and sharia is primarily based on Quran). Therefore, a culture which upholds religiosity will promote mutual forgiveness.

Next, the result of the study illustrates the role of self-orientation to forgiveness. According to Idrus [14], self-orientation consists of patience, honesty, and self-control. Mertawardaya [26] describes patience as an act of tolerance and endurance; yet, it is dissimilar to anxiety. Honesty is perceiving and explaining an information as it is. When a person is unable to explain a condition as it supposes to be, he/she is being dishonest, untrustworthy, hypocrite, etc. Self-control means a person's capacity to manage his/her mind and feeling expressed in nata swara (a conscience to said the truth), bener tur pener (accurate and truthful) [27]. There are two studies which come to similar results. Worthington, Witvliet, Lerner, and Scherer [28] illustrates that self-control is closely related to forgiveness and Oman, Shapiro, Thoresen, Plante, and Flinders [29] also show that meditating habit can lessen stress and improve forgiveness among students.

The next result shows that there is no significant correlation between collective orientation to forgiveness which is in contrary to preceding studies. Nashori and Setiono [25] mention that Javanese has distinctive habits or behavioral patterns in expressing their feelings publicly, especially the agonizing one. Javanese learns to endlessly keep harmony of his/her surroundings. Thus, he/she needs to be careful in expressing his/her feeling. A Javanese proverb which reflects this principle is mikul dhuwur mendhem jero (recall the kindness of others and overlook their mistakes). By mendhem jero (overlooking others' mistakes), Javanese is able to maintain the harmony of his/her surroundings. The result highlights that internal cultural values give bigger influence to forgiveness than external values. Besides, another result indicates that there is a correlation between connectivity and forgiveness in a community. Collectivity is a power that regulates social harmony in a community; therefore, the community will be cohesive and appreciative [30]. The other result proves that there is a positive correlation between marital values to forgiveness and family harmony Commitment agreed by married couple makes forgiveness in resolving conflict occurs smoothly [31]

\subsection{Personality Traits and Forgiveness}

The research result indicates that there is a positive correlation between personality traits and forgiveness; accordingly, it strengthens the findings of prior researches. McCullough [16] specifies that personality considerably influences forgiveness. Allemand, Amberg, Zimprich, and Fincham [32] also assert that personality contributes in the satisfaction of interpersonal relationship in an episode of forgiveness among couples.

The research results share similarities and differences with studies by Firdaus [17] and Nashori, et., al [11]. In this study, personalities that have positive correlation with forgiveness are openness, conscientiousness, agreeableness, and extraversion. In contrary, personality that has negative correlation with forgiveness is neuroticism. Prior studies indicate: (a) there is a positive correlation between agreeableness and forgiveness [17,11], there is a positive correlation between extraversion and forgiveness [17] and there is a positive correlation between openness to experience and forgiveness [17] (b) there is a negative correlation between neuroticism and forgiveness [17,11] and there is a negative correlation between conscientiousness and forgiveness [17]. Therefore, this research results are consistent with Firdaus [17] and Nashori et., al, [11], in term of correlation among openness, agreeableness, and extraversion with forgiveness and correlation between neuroticism and forgiveness. 
However, this research shows there is a positive correlation between conscientiousness and forgiveness which is in contrary to Firdaus [17].

Moreover, this research describes that there is a positive correlation between openness to experience and forgiveness. Openness to experience is closely related to aptitude, creativity, humbleness, and politeness [16]. Openness to experience is also associated with intelligence, imagination, and artistry. An individual with openness to experience has imaginative analytical capacity to solve problems. According to social attribution theory, an individual in social context uses information to clarify things. Baron and Byrne [33] explain that social attribution is an effort to understand the causes of people's behavior. Wortman, Loftus, Kremer and Stephens [34] mention that information on certain causes of an event is the effective information that prevents a person from making revenge. A research by Firmansyah and Prawasti [35] describes research's subjects understanding on their daughters' pre- marital pregnancies and their intrapersonal and intrapsychic forgiveness capacities. Takaku [36] says that a forgiving individual commonly concludes that abuser has admitted his/her mistake and not personally intended to do it. Change in perspective on this agonizing situation provides positive emotional reaction and leads to forgiveness to the abuser.

This research result also indicates that there is a positive correlation between extraversion and forgiveness. Extraversion or surgency describes some characters, like, friendliness, freedom of expression, and self-assurance. An individual with high rate of extraversion will immediately mingle, love to influence and compete with others, and active in group's activity. Guilford and Braly [37] mention that extraversion is a vast dimension that is frequently discussed in broad-spectrum of personality traits. It reflects directness, sociability, and assertiveness. Extraversion is closely related to individual's quality of social interaction [19]. Jung [37] describes this extraversion personality from the perspective of way of thinking, common sense, belief, and intuition. People with extraversion personality try to understand and interpret external aspects of their environments. They are logical, obedient, practical, objective, and dogmatic. These extraversion people also aim to create balanced life, tend to be easy going, and preserve tradition and authority; however, they may appear emotional and persistently emphasize their ideas. Extraversion people tend to be realistic, factual, adventurer, and intuitive. Moreover, they are keen to explore external environments, get easily bored, tend to be creative, and swiftly find interesting ideas. A study by McCrae and Allik [38] illustrates that individual with agreeableness and extraversion traits is tender, reliable, cooperative, compliant, and forgiving.

The research result also indicates the correlation between agreeableness and forgiveness. McCullough [16] and Nashori et., al, [11] explain that agreeableness is an indication of forgiving personality since the dimension of agreeableness covers natures, such as, sincere, cooperative, selfless, pleasant, truthful, considerate, well-mannered, and adaptable. People with agreeableness trait tend to be emphatic and outgoing. Agreeableness, according to Costa and McCrae [19] consists of three interrelated traits, namely, sensitivity, caring, and affection. McCullough et al [39] and Takaku [36] find that empathy is closely related to role taking. By showing empathy to his/her opponent, a person can understand the abuser's guilt and despair for agonizing others. Thus, some researchers indicate that empathy takes part in forgiveness. Saputro and Nashori [40] show that there is a positive correlation between forgiveness and agreeableness with resilience. There is also a significant positive correlation between interpersonal trust and forgiveness on friendship among students in the age of 18-21 [41]. Furthermore, quality of friendship and empathy has positive correlation with forgiveness among students in the age of 17-21 [42] 
Next, the result also indicates that there is a positive correlation between conscientiousness and forgiveness. Conscientiousness covers characteristics, like, wellplanned and highly responsible. People with conscientiousness trait tend to be well-organized, full of commitment, self- motivated, and relationship-oriented [43]. However, this research has different result from previous researches. The previous ones indicate that conscientiousness does not consistently influence forgiveness $[17,38,44]$. The main cause is high commitment in responsibility which builds up to forgiveness. Responsibility makes an individual with conscientiousness trait committed to the welfare of every member of his/her community, including his/her abuser. Other research results illustrate that there is a correlation between self-forgiveness process and level of procrastination among university students [45] and a negative correlation between forgiveness and self- blame [46]

The final result discloses a negative correlation between neuroticism and forgiveness; hence, it strengthens the findings of prior researches [17, 38,]. McCrae and Costa [47] assert that neuroticism is a part of personality traits that often triggers anxiety. In terms of commitment, an individual with neuroticism trait has higher chance of having negative emotions, like, anger, sadness, stress, angst, and depression. Therefore, the individual is prone to experience stress, depression, and resentment, especially, at the time he/she is in tense situation. Another result indicates that there is a negative correlation between procrastination and forgiveness in which the lower the procrastination, the higher the level of forgiveness [48].

Acknowledgements. This research was granted by the directorate of research and community service of Universitas Islam Indonesia, Yogyakarta, Indonesia

Orcid. Fuad Nashori http://orcid.org/0000-0001-7826-3386

\section{References}

[1] Somov, A.: Wildfire safety with wireless sensor networks. EAI Endorsed Transactions on Ambient Systems. pp. 1-11 (2011)

[1] Thompson, L. Y., Snyder, C. R., Hoffman, L., Michael, S. T., Rasmussen, H. N., Billings, L. S., Heinze, L., Neufeld, J. E., Shorey, H. S., Roberts, J. C., Robert, D. E.: Dispositional fogiveness of self, other, and situation. Journal of Social and Personality Psychology, 73 (2), 313-359. (2005)

[2] Chan, D. W.: Subjective well-being of Hong Kong Chinese teachers: The contribution of gratitude, forgiveness, and the orientations to happiness. Teaching and Teacher Education, 32, 22-30. (2013)

[3] Rienneke, T. C., Setianingrum, M. E.: The correlation of forgiveness and happiness among adolescence in orphanages (Hubungan antara forgiveness dengan kebahagiaan pada remaja yang tinggal di panti asuhan). Persona: Jurnal Psikologi Indonesia, 7 (1), 18-31. (2018).

[4] Aziz, R., Wahyuni, E. S., Wargadinata, W.: The contribution of gratitude and forgiveness to increase mental health (Kontribusi bersyukur dan memaafkan dalam meningkatkan kesehatan mental). Insan: Jurnal Psikologi dan Kesehatan Mental, 2 (1), 33-43. (2017)

[5] Raj, P., Elizabeth, C.S., Padmakumari, P.: Mental health through forgiveness: Exploring the roots and benefits. Journal of Cogent Psychology, 3 (1), 1-16. (2016) 
[6] Hafnidar., Chang, L., Lin, H.: Forgiveness as a mediator for the relationship between spirituality and posttraumatic growth in Aceh Conflict Victims Indonesia. International Journal of Social Science and Humanity, 2 (3). (2012)

[7] Habibi, M. M., Hidayati, F.: Hubungan antara pemaafan diri sendiri, pemaafan orang lain dan pemaafan situasi dengan resiliensi pada mahasiswa baru. Jurnal Empati, 6 (2), 62 69. (2017)

[8] Rahmandani, A.: Forgiveness and cognitive aspect of stress among college students (Pemaafan dan aspek kognitif dari stres pada mahasiswi jurusan kebidanan). Jurnal Psikologi, 14 (2), 118-128. (2015)

[9] Nashori, H. F., Mayasari, G., Dewisukma, G., Iskandar, D., Wicaksono, K., Prehastamto, C., Andriansyah, Y.: The model of bullying behavior on senior High School: A case study in Indonesia. Psychology and Education Journal, 54 (1-2), 65-75. (2017). https://doi.org/10.1016/j.tate.2012.12.005

[10] Nashori, H. F., Iskandar, T. Z., Setiono, K., Siswa, A. G. P.: Forgiveness themes among Yogyakarta college students (Tema-tema pemaafan mahasiswa Yogyakarta). Research report. Fakultas Psikologi dan Ilmu Sosial Budaya UII. Yogyakarta. (2011)

[11] Nashori, H. F., Iskandar, T. Z., Setiono, K., Siswa, A.G. P.: Psikologi pemaafan, Safiria Insania Cita. Yogyakarta. (2015)

[12] Kuntari, U.: Kata-kata super motivasi bijak leluhur Jawa, Eule Book. Yogyakarta. (2010).

[13] Goble, F. G.: The third force: The psychology of Abraham Maslow, Grossman. Oxford, UK. (1970)

[14] Idrus, M.: Existential faith among Javanese adolescence (Kepercayaan Eksistensial Remaja Jawa. Dissertation, Fakultas Psikologi UGM. Yogyakarta. (2004)

[15] Nurwianti, F., Oriza, I. D.: Explorative study of character strengths on Indonesian people (Java, Sunda, Minahasa, Betawi, Bugis, and Batak). Paper presented on The First International Conference of Indigenous and Cultural Psychology, July 24-27, Yogyakarta. (2010)

[16] McCullough, M. E.: Forgiveness: Who does it and how do they do it? Current direction in Psychological Science. American Psychological Society, (2001) pdf.

[17] Firdaus, F.: The correlation of personality trait and marital commitment with forgiveness to couple's lies on marital Bugisese (Hubungan tipe kepribadian dan komitmen perkawinan dengan pemaafan terhadap kebohongan pasangan dalam perkawinan Bugis). Thesis, Fakultas Psikologi UGM. Yogyakarta. (2008).

[18] Subandi, M. A.: Validity and reliability forgiveness construct (Validitas dan Reliabilitas Konstruk Pemaafan). Research report, Faculty of Psychologi Universitas Gadjah Mada. Yogyakarta. (2010)

[19] Costa, P. T., Jr., McCrae, R. R: Longitudinal stability of adult personality. In R. Hogan, J. A. Johnson, \& S. R. Briggs (Eds.). Handbook of personality psychology (pp. 269290), Academic Press. Orlando, FL. (1997).

[20] Koentjaraningrat.: Kebudayaan Jawa, PN Balai Pustaka. Jakarta. (1999)

[21] Suharsono, M., Susetyo, D. B.. Karakteristik pemaafan berbasis budaya Jawa. Psikodimensia, 16 (1), 81-90. (2017)

[22] Sandage, S. J., Hill, P. C., Vang, H. C.: Toward a multicultural positive psychology: Indigenous forgiveness and Hmong culture. The Counseling Psychologist, 31 (5), $564-$ 592. (2003)

[23] von Feigenblatt, O.: Forgiveness and culture: An interdisciplinary dialogue. Journal of History and Social Sciences, 1 (1), 1-9. (2010) 
[24] Magnis-Suseno, F.: Etika Jawa: Sebuah analisa filsafati tentang kebijaksanaan hidup Jawa, PT Gramedia. Jakarta. (1999)

[25] Nashori, H. F., Setiono, K.: Forgiveness in Javenese ethnicity. Jurnal Psikoislamika, 7 (1), 11. (2010)

[26] Mertawardaya, S.: Pusaka Sasangka Jati, Badan Penerbitan dan Perpustakaan Pangestu Pusat. Jakarta, cetakan kelima. (1983)

[27] Susanto, E., Soekardji., Setiawan, H. I.: Pengkajian nilai-nilai luhuir budaya spiritual Daerah Jawa Timur, Departemen Pendidikan dan Kebudayaan. Jakarta. (1992)

[28] Worthington, E. L., Witvliet, C. O., Lerner, A. J., Scherer.: Forgiveness in health research and medical practice, Explore, 1 (3), 169-176. (2005)

[29] Oman, D., Shapiro, S. L., Thoresen, C. E., Plante, T. G., \& Flinders, T.: Meditation lowers stress and supports forgiveness among college students: A randomized controlled trial. Journal of american college health, 56 (5), 569-578. (2008)

[30] Hook, J. N., Worthington Jr, E. L., Utsey, S. O.: Collectivism, forgiveness, and social harmony. The Counseling Psychologist, 37 (6), 821-847. (2009)

[31] Nancy, M. N., Wismanto, Y. B., Hastuti, L. W.: The correlation of marital values and forgiveness wirh family harmony (Hubungan nilai dalam perkawinan dan pemaafan dengan keharmonisan keluarga). Psikodimensia, 13 (1),84. (2014)

[32] Allemand, M., Amberg, I., Zimprich, D., Fincham, F.D.: The Role of trait forgiveness and relationship satisfaction in episodic forgiveness. Journal of Social and Clinical Psychology, 26 (2), 199-217. (2007)

[33] Baron, R. A., Byrne, D: Social psychology: Understanding human interaction, Allyn and Bacon. Boston. (2004)

[34] Wortman, C., Loftus, E., Kremer, J. F., Stephens, L.: Attributions and arousals as mediators of mitigation's effect of retaliation. Journal of Personality and Social Psychology, 45, 335-343. (1983)

[35] Firmansyah, A. F., Prawasti, C. Y.: Parent forgiveness and causal attribution to daughter's premarital pregnancy moment (Pemaafan orangtua dan atribusi kausal terhadap peristiwa kehamilan pranikah anaknya). Jurnal Psikologi Sosial, 14 (02), 165 179. (2008)

[36] Takaku, S.: The affects of apology and perspective taking on interpersonal forgiveness: A dissonance-attribution model of interpersonal forgiveness. Journal of Social Psychology, 141 (4), 494-508. (2001)

[37] Raad, B. D.: The Big five personality factors: The psycholexical approach to personality, Hogrefe \& Huber Publishers. Seattle. (2000)

[38] McCrae, R. R., Allik, J.: The Five factor model of personality across cultures, Kluwer Academic/Plenum Publishers. New York. (2002)

[39] McCullough, M. E, Fincham, F. D., Tsang, J.: Forgiveness, forbearance and time: The temporal unfolding of transgression-related interpersonal motivations. Journal of Personality and Social Psychology, 84 (3), 540-557. (2003)

[40] Saputro, I., Nashori, F.: Resilience among college students viewed by forgiveness and agreeableness trait (Resiliensi mahasiswa ditinjau dari pemaafan dan sifat kepribadian agreeableness). Jurnal Psikologi Islam, 4 (2), 171-180. (2018)

[41] Utami, D. A.: Interpersonal trust and forgiveness in friendship relation (Kepercayaan interpersonal dan pemaafan dalam hubungan persahabatan). Jurnal Ilmiah Psikologi Terapan, 3 (1), 54-70. (2016) 
[42] Angraini, D., Cucuani, H.: The correlation between intimate relationship and empati with forgiveness among late adolescence (Hubungan kualitas persahabatan dan empati pada pemaafan remaja akhir). Jurnal Psikologi, 10 (1), 18-24. (2014)

[43] Feist, J., Feist, G. J.: 2008. Theories of personality, Pustaka Pelajar. Yogyakarta.

[44] Watkins, D., Regmi, M.. Personality and forgiveness: A Nepalesse perspective. The Journal of Social Psychology, 144 (5), 539-351. (2004)

[45] Wohl, M. J., Pychyl, T. A., Bennett, S. H.: I forgive myself, now I can study: How selfforgiveness for procrastinating can reduce future procrastination. Personality and Individual Differences, 48 (7), 803-808. (2010)

[46] Vallade, J. I., Myers, S. A.: Student forgiveness in the college classroom: Perceived instructor misbehaviors as relational transgressions. Communication Quarterly, 62( 3), 342-356. (2014)

[47] McCrae, R. R., Costa, P. T.: Personality in adulthood: A five-factor theory perspective, The Guilford Press. New York. (2003)

[48] Rahmandani, A.: Forgiveness and academic procrastination among college students (Pemaafan dan prokrastinasi akademik mahasiswa). Jurnal Psikologi Undip, 16 (1), 6476. (2017) 